\title{
PARTICIPATION OF LECTINS IN THE FORMATION OF PLANT PROTECTIVE REACTIONS OF CEREALS
}

\section{УЧАСТИЕ ЛЕКТИНОВ В ФОРМИРОВАНИИ ЗАЩИТНЫХ РЕАКЦИЙ ЗЛАКОВ}

\section{Olga Molodchenkova ${ }^{1}$ \\ Olga Ryshchakova ${ }^{2}$}

DOI: https://doi.org/10.30525/978-9934-588-15-0-77

Abstract. The purpose of the paper is to summarize and present the literature and our results about role of lectins in the formation of plant response reactions to the action of biotic and abiotic factors, its connection with other plant defense factors and resistance to phytopathogenes and abiotic stressors. Methodology. The researches were conducted using varieties, lines and genotypes of winter wheat (Triticum aestivum L.), spring barley (Hordeum vulgare L.) and maize (Zea mays L.) that differ in their resistance to fungal pathogens, drought and heat tolerance. Salicylic acid and jasmonic acid were used as signal molecules. Lectin activity was studied by method of hemagglutination response of white rats trypsinised erythrocytes. Determination of gene expression of lectin was detected using RT-PCR. Statistical analysis of experimental data was carried out according to the parametric criteria of the normal distribution option, the standard deviation of the mean values - according to the generally accepted method. Results. Changes of the activity, carbohydrate specificity and component composition of soluble lectins and lectins of the cell walls of cereals under the influence of fungal infection, abiotic stressors and signal molecules (salicylic acid and jasmonic acid) were established. The level of cereals genotypes resistance to fungal pathogens (Fusarium spp., Alternaria spp., Bipolaris spp.) and drought and heat tolerance affected the rate of these changes. It was elucidated that the changes of lectin activity in the cereals at the action of factors

\footnotetext{
${ }^{1}$ Doctor of Biological Sciences, Head of Laboratory of Plant Biochemistry,

Plant Breeding \& Genetics Institute-National Center of Seed and Cultivar Investigation, Ukraine

${ }^{2}$ Research Associate of Laboratory of Plant Biochemistry,

Plant Breeding \& Genetics Institute-National Center of Seed and Cultivar Investigation, Ukraine
}

(C) Olga Molodchenkova, Olga Ryshchakova 
of different nature are controlled by different mechanisms. These changes depend on the expression of lectin genes and intensity of protein biosynthesis. Lectins from germ and wheat, barley, maize seedlings in normal conditions, infected by Fusarium spp., treated by salicylic acid were isolated by methods of gel-filtration, affinity chromatography and isoelectric focusing, their biochemical properties were studied. It is showed that isolated preparations of lectins suppressed the development of colonies of fungi Fusarium graminearum, Fusarium culmorum. One of display of protective action of isolated lectins is their positively influence on the growth processes of noninfected and infected plants, skill to induce the changes of protective proteins activity (activity of trypsin inhibitor, lectins, lipoxygenase, phenylalanineammonia-lyase) in the plant tissues of cereals. Practical implications. It is concluded about possibility of employment of isolated lectins in the molecular-breeding programs of increase of cereals towards fungal pathogens. The carried out research allowed to make theoretical grounds and experimentally realize new biochemical approaches to evaluation of plant resistance to fungal diseases and abiotic stressors. It was got 3 Ukrainian patents for new express methods for selection of Fusarium-resistant and drought-tolerant or heat-tolerant cereal crops genotypes using biochemical parameter (lectin activity) (declarative Ukrainian patent \#43280, declarative Ukrainian patent \#69859, declarative Ukrainian patent \# 49643).

\section{1. Вступление}

Лектины - белки со специфическими биологическими свойствами, способные обратимо и избирательно связывать углеводы, не вызывая их химического преобразования. Существует несколько подходов к классификации лектинов, в основу которых положены разные принципы:

- по происхождению лектины разделяют на: лектины растений (фитолектины), грибов, микроорганизмов, вирусов и животных; связанные и несвязанные с мембранами клеток; лектины, специфичные для органа, ткани или клеток определенного живого организма и т.д.;

- по биологической активности лектины подразделяются на: эритроагглютинины; лейкоагглютинины; митогены; агглютинины половых клеток; токсины; бифункциональные лектины;

- по строению молекулы лектины подразделяют на: чистые белки; гликопротеины (когда содержание углеводов в составе молекулы 
меньше 50\%); протеогликаны (содержание углеводов составляет 50-60\%), металлопротеины (когда в составе лектина и для проявления его активности необходимо наличие ионов металла); по числу субъединиц, входящих в состав молекулы (мономеры, димеры, тетрамеры и молекулы с большим числом субъединиц);

- существуют также классификации лектинов по углеводной специфичности и структуре доменов углеводного распознавания $[9$, с. 3$]$.

Важнейшей функциональной частью домена углеводного распознавания является центр связывания или место связывания углеводов. Углевод и лектин взаимодействуют по классической схеме энзим-субстратного взаимодействия. Однако, в отличие от ферментов-гликозидаз, они не вызывают химических преобразований. Лектины растений достигают высокой аффинности вследствие мультивалентности, которой они обладают в димерной и тетрамерной форме. Четвертичная структура лектинов может также вносить вклад в распознавание гликанов. Способность каждой субъединицы индивидуально связывать сахара может привести к поперечно-связанной решетчатой структуре, что показано для лектина сои в его взаимодействии с 4 изомерными N-гликанами, а также для агглютинина зародышей пшеницы [10, с. 427-428]. Такая способность формировать решетчатые структуры позволяет лектинам формировать сложные взаимодействия с поверхностью клеток и матричными гликоконьюгатами, имеющими значительное количество мест связывания, которые, возможно, вносят вклад в биологическую активность лектинов. Размер места связывания углеводов у разных лектинов может существенно различаться. У разных лектинов центры связывания обеспечивают тонкие отличия в углеводной специфичности. Большинство лектинов имеют несколько центров связывания углеводов, которые могут обладать разной специфичностью. Если они расположены на разных субъединицах, возможно образование нескольких изоформ с различными иммунохимическими и биологическими свойствами [17, с. 123].

На протяжении жизненного цикла организмов активность лектинов претерпевает определенные изменения [11, с. 1220]. Эти изменения могут быть качественными и количественными. Биологическая суть таких изменений не до конца исследована, но они являются, без сомнения, важными для жизнедеятельности живых организмов. У большин- 
ства видов растений активность лектинов зависит от фазы вегетации. Кроме того, иногда это может сопровождаться изменениями углеводной специфичности.

Рядом автором был установлен полиморфизм лектинов. Например, исследование с помощью ионообменной хроматографии гемагглютининов Phaseolus vulgaris показало наличие пяти изолектинов, которые являются комбинацией эритроцитарных (E) и лейкоцитарных (L) реактивных субъединиц по следующей схеме - L4, L3E4, L2E2, L1E3, E4 [29, с. 43]. Множественные формы лектинов были установлены у пшеницы, сои и других культур. Изолектины могут быть продуктами экспрессии аллельных генов или результатом генетически детерминированных посттрансляционных модификаций молекул лектинов $[39$, p. 5]. Показано, что иммунохимическая гетерогенность и специфичность лектинов связана с уровнем плоидности, геномным составом и отражает геномспецифическую устойчивость зерновых культур и картофеля. Лектины могут использоваться для маркирования вида и генома, геномного анализа, выяснения путей происхождения культурных растений, степени родства с дикими сородичами и для подбора пар при отдаленной гибридизации с целью получения жизнеспособного потомства [37, с. 6].

Известные и предполагаемые функции растительных лектинов можно разделить на структурные (упаковка запасных гликопротеидов, гликопротеидов мембран, ферментных комплексов), транспортные (транспорт моно- ди- и полисахаридов, белковых субъединиц), регуляторные (блокирование олигосахаридных групп, регуляция активности ферментов-гликопротеидов и ферментов-лектинов) и информационные (узнавание и иммобилизация патогенов и элиситоров) [12, с. 1008; 34, с. 109-110].

В ряде обзорных работ [12, с. 1011-1018; 13, с. 224-230; 35, с. 111-120] приведены многочисленные литературные, экспериментальные данные о возможной защитной роли лектинов против фитопатогенов и различных абиотических стрессоров. Однако конкретные механизмы защитного действия лектинов еще окончательно не выяснены и остаются дискуссионными. Анализ литературных данных и результатов наших исследований, связанных с этими вопросами, и явились целью этой статьи. 
В лаборатории биохимии растений Селекционно-генетического института-Национального центра семеноведения и сортоизучения исследования активности, углеводной специфичности, компонентного состава лектинов в связи с устойчивостью к грибным патогенам, проводили на линиях, сортах озимой и яровой пшеницы (Triticum aestivum L.), ярового ячменя (Hordeum vulgare L.), кукурузы (Zea mays $L$.), различающихся по устойчивости к возбудителям фузариоза, альтернариоза и гельминтоспориоза.

Это - устойчивые к возбудителям фузариоза сорта пшеницы Ласточка одесская, Выхованка одесская, Эритроспермум 80/06, линии - 5/20-91, 1/74-91; сорта ярового ячменя - Вакула, Нутанс 244 , Одесский 115, Одесский 151; линии кукурузы - ГК 26, А 634 , HMv404, Од 139, ОК 124-2, ОК 119-1, Дк 277-10, Дк 377, Дк 369/541; устойчивые к возбудителям альтернариоза сорта пшеницы Никония, Виктория; устойчивые к возбудителям гельминтоспориоза генотипы ярового ячменя 95-111-7, 94-1-3, 94-141-5, 94-123-9, 94-102-3, сорт ярового ячменя Одесский 151; восприимчивые к возбудителям фузариоза сорта пшеницы Одесская полукарликовая, Юннат одесский, Никония, Харьковская 26; сорта ярового ячменя Водограй, Рось, Чудовый; линии кукурузы СМ 7, R 1-2 ВМ, Т 135, Т 22, Е 35, МАН 204A, БС 0135, Ик 105-4, ДС 10/3 МВ, Од 220, ОК 293-2; восприимчивый к возбудителям альтернариоза сорт пшеницы Одесская полукарликовая; восприимчивые к возбудителям гельминтоспориоза генотипы ярового ячменя 94-155-13, 95-111-6,95-241-20, 95-80-11, 92-187-9, 93-177-33, 94-66-5, сорт ярового ячменя Адапт.

Исследования биохимических механизмов засухоустойчивости проводили на линиях, сортах озимой и яровой пшеницы (Triticum aestivum L.), ярового ячменя (Hordeum vulgare L.), линиях кукурузы (Zea mays L.), различающихся по уровню засухоустойчивости. Это - засухоустойчивые сорта пшеницы Одесская 16, Безостая 1, Одесская 51, Сирена, Миссия; сорта ярового ячменя Сталкер, Адапт; линии кукурузы Од 329, Од $221 \mathrm{MB}$, Од $7 \mathrm{MB}$, П29-231-1, ИК107 зМ, ГКБ23/119-31, Од221MВ, МСА224-131, ИК107 ВС $/ 53$ МВ, ЛБ329/22, ЛБF2/Mo17-28/421; слабозасухоустойчивые сорта пшеницы Славея, Serio 16, Jara, Басарка; сорта ярового ячменя Вакула, Оболонь; линии кукурузы ГК 26, СМ 7 SL, ГКБ23/NS183-111, ЛБ 228, MC4A224-112, ИК107 ВС $/ 66$. 
Материал для исследований (семена сортов и линий зерновых культур) был предоставлен отделами селекции и семеноводства пшеницы, ячменя и кукурузы, отделом фитопатологии и энтомологии СГИ - НЦСС.

В опытах использовали неповрежденные зерновки озимой и яровой пшеницы, ярового ячменя и кукурузы, которые проращивали на фильтровальной бумаге в термостате при $25^{\circ} \mathrm{C}$ и относительной влажности воздуха $60 \%$ в течение 3-7 суток. Заражение растений патогенами проводили, выращивая проростки на среде, содержащей $1 \times 10^{5}$ конидий/мл патогенных штаммов К90 Fusarium Graminearum Schwabe, Fusarium culmorum, Fusarium moniliforme, Alternaria alternata, Bipolaris sorokiniana. Водный дефицит создавали, помещая проростки на сухую фильтровальную бумагу в камеру с влажностью воздуха $35-40 \%$. Гипертермию создавали путем размещения растений в термостате при $39-42^{\circ} \mathrm{C}$. Длительность действия водного дефицита и гипертермии - 6 часов. Обработку растений салициловой кислотой проводили, выращивая растения в течение 3-7 суток на фильтровальной бумаге, смоченной 0,007-2 мМ растворами салициловой кислоты. При совместном действии патогена и салициловой кислоты, замоченные в течение ночи в 0,007-0,1 мМ растворах салициловой кислоты зерновки, высаживали на суспензию с патогеном. Предобработку проростков зерновых культур перед воздействием абиотических стрессоров проводили путем опрыскивания растений 0,007 мМ раствором салициловой кислоты. Обработку растений жасмоновой кислотой проводили путем опрыскивания 1 мкМ раствором. Обработка растений ингибитором синтеза белка циклогексимидом проводилась в концентрации $10 \mathrm{мг} /$ л на протяжении 2 часов. По окончании экспозиции отпрепарированные надземную часть и корни проростков замораживали при $-70{ }^{\circ} \mathrm{C}$, лиофильно высушивали и размалывали. При изучении влияния экзогенного лектина на ростовые и адаптивные процессы растений зерновых культур, а также на развитие колоний грибов рода Fusarium использовали выделенные очищенные препараты лектинов в концентрации от 1 до 100 мкг/мл.

Растворимые лектины и лектины клеточных стенок из надземной части и корней проростков извлекали согласно методике Комаровой Э.Н. [16, с. 681-682]. Лектины зародышей зерна экстрагировали $0,2 \mathrm{M} \mathrm{NaCl}$ в соотношении навески к экстрагенту 1:21. Лектин сои 
выделяли из семян сои методом поэтапного этанольного фракционирования [30, с. 282]. Активность лектинов определяли в планшетках для иммунологических исследований по их способности агглютинировать трипсинизированные эритроциты белых крыс [18, с. 56-57]. Лектиновую активность рассчитывали по минимальному количеству белка, вызывающего агглютинацию эритроцитов (мкг белка/мл)-1. Углеводную специфичность лектинов определяли по их сродству к углеводам [18, с. 58-60]. Для этого использовали следующие углеводы: D-глюкозу, D-фруктозу, сахарозу, D-ксилозу, D-галактозу, D-рафинозу, N-ацетилглюкозамин, D-глюкозамин, D-галактозамин, D-фруктозо-6-фосфат в исходной концентрации 500 мМ. О степени сродства лектинов к экзогенным сахарам судили по наименьшей концентрации сахара, при которой наблюдали отсутствие агглютинации.

Определение экспрессии генов лектина и фенилалалнинаммиаклиазы по количеству мРНК проводили методом обратной транскрипции с использованием полимеразно-цепной реакции в реальном времени (RT-PCR) [38, p.12-13]. Данные о нуклеотидных последовательностях генов лектина и фенилаланинаммиаклиазы получили с нуклеотидной базы Национального Центра Биотехнологической Информации США (National Center for Biotechnology Information US) (PubMed). Подбор праймеров осуществляли с помощью программы Primer3 (version 0.4.0).

Статистическая обработка результатов исследований проводилась с помощью программы Libre Office Calc (GNU Lesser General Public Licensev3), методов многомерной статистической обработки данных с использованием программы “AGROBASE”, программы анализа изображений “ImageJ". В работе представлены средние значения и их стандартные ошибки, отличия между вариантами опытов, различающими по устойчивости к патогенам сортами, линиями считали достоверными при уровне значимости $\mathrm{P}<0,05$ по критерию Стьюдента.

\section{2. Роль лектинов в проявлении устойчивости к патогенам}

Одной из функций лектинов является специфическое связывание углеводных компонентов чужеродных организмов, их инактивация и защита растения от поражения [20, с. 113]. Показано, что лектины цитоплазматических мембран клеток бобовых специфически связывают углеводы и углеводсодержащие полимеры клеточных стенок 
Colletotrichum lindemuthianum и Phytophtora megasperma. В результате этого грибы локализуются на поверхности растения, после чего включаются механизмы, активизирующие образование неспецифических компонентов защиты - фитоалексинов. Лектины других культур (картофеля, батата, зародышей пшеницы, табака, хлопчатника, соевых бобов) также проявляют высокую специфичность по отношению к связыванию углеводных компонентов грибных и бактериальных клеток $[28$, с. $34-35)$. Механизм взаимодействия лектинов с углеводными компонентами этих патогенных грибов был рассмотрен на примере фитопатогенной системы картофель-Phytophtora infestans [20, с. 10]. Оно осуществляется по принципу рецепторно-лигандного управления. Растительный гликопротеин (рецептор) специфически связывается $\mathrm{N}$-ацетил-D-глюкозамином патогена (лигандом), имеющего длину цепи, включающую 2-5 совмещенных друг с другом остатков по $\beta-1,4-$ связям, которые называются гаптены. Их предназначение - образование межклеточного контакта, а в результате и развитие защитной реакции картофеля. Комплементарный контакт с лигандом, который проявляется в форме узнавания, включает в работу соответствующие гены, результат активирования которых - формирование устойчивости растения в виде сверхчувствительной реакции частей ткани, что способствует отторжению возбудителя фитофтороза. При развитии восприимчивой реакции белок-углеводное узнавание проходит медленно, в результате в тканях картофеля идет медленное накопление фитоалексинов, под воздействием которых проникающий патоген постепенно погибает. В результате замедленной ответной реакции тканей картофеля патоген может проникнуть в другие клетки клубня картофеля.

Одним из признаков участия белков в реакции устойчивости/ восприимчивости растения является количественное изменение их уровня или активности. Так, например, была обнаружена взаимосвязь между активностью гемагглютинации водорастворимых лектинов в листях и клубнях картофеля, которые обладают, как и АЗП, специфичностью к N-ацетил-D-глюкозамину, и устойчивостью картофеля к фитофторозу [15, с. 5-6]. Показано, что семена сортов сои, устойчивых к Phytophtora megasperma var.sojae, характеризовались вдвое большим содержанием лектина по сравнению с восприимчивыми сортами [41, p. 562-563]. 
В основе защитных функций лектинов, по мнению некоторых авторов $[13$, с. $230 ; 16$, с. 683$]$ лежит передача сигналов извне в середину клетки или органелл, что связано с ионными потоками, вызванными изменением проницаемости мембран в результате взаимодействия мембранных лектинов с определенными гликоконьюгатами. Так, в тканях молодого корнеплода буряка лектины выявлены в мембранах всех клеточных органелл, тогда как в зрелом - лишь на поверхности клеток и во фракции микросом [14, с. 528]. Характер локализации лектинов и непостоянное наличие их в тканях корнеплода сахарного буряка позволили авторам предположить, что лектины являются периферическими функциональными компонентами мембран, которые взаимосвязаны с уровнем метаболической активности клеток и принимают участие в восприятии сигналов извне как клеткой, так и ее отдельными компартментами.

Серьезным доводом в пользу участия лектинов в защите растений при патогенезе являются результаты по индукции накопления лектинов при обработке растений элиситорами, а также под влиянием обработки байтаном, бисолом 2, повышающих устойчивость растений к грибным болезням [32, с. $114 ; 33$, с. 140]. Установлено, что фунгицид байтан, препарат бисол 2 , обладающий свойством иммунизатора, а также салициловая кислота, являющаяся индуктором системной приобретенной устойчивости, вызывают существенное увеличение содержания лектина в проростках. По данным Шакировой с соавторами, все эти антистрессовые регуляторы индуцируют накопление АБК в растениях, и вызываемое ими увеличение уровня лектина является АБК-контролируемым и таким образом лектин вовлекается в механизмы защитного действия этих соединений, способствующих преадаптации растений к стрессовым ситуациям [35, с. 60-61]. Сравнение особенностей синтеза лектинов и других белков растений при инфицировании и обработке соединениями - участниками разных сигнальных систем (салициловой кислотой, сукцинатом, жасмонатом) дало дополнительную информацию о возможном механизме формирования реакции растений на инфекцию. Результаты, полученные при инокуляции растений гороха микоплазмами, позволили предположить возможность индукции инфицированием двух сигнальных систем (НАДФН-оксидазной и липоксигеназной), которые активируются в 
результате взаимодействия первичных сигналов (элиситоров или олигохаридов) с белковыми рецепторами плазмалеммы. Участники этих сигнальных систем способны активизировать разные протеинкиназы, которые фосфорилируют белки, в том числе и факторы регуляции транскрипции, а при их участии - активируют промоторные участки защитных генов и тем самым - синтез кодируемых ими защитных белков (в том числе, лектинов), что приводит к формированию устойчивости к патогенам [31, с. 200].

В литературе есть данные относительно биорегуляторного влияния экзогенных лектинов на растения. Так, экзогенная обработка семян сои лектинами, выделенными из нее, стимулировала выход из состояния покоя, формирование зеленой массы и корневой системы на ранних этапах онтогенеза, значительное увеличение урожая. Использование лектинсодержащих экстрактов для предпосевной обработки семян растений разных таксономических групп - однодольных (пшеницы) и двудольных (гороха) не только интенсифицировало ростовые процессы на стадии проростков, а и способствовало индукции активности пероксидазы и каталазы как индикаторов повышенной устойчивости к патогенам [36, с. 38].

Однако, несмотря на многочисленность литературных данных, свидетельствующих об участии лектина в механизмах защиты растений при инфицировании патогенами, защитная его роль не является полностью доказанной. Одним из наиболее хорошо изученных лектинов растений является агглютинин зародышей пшеницы (АЗП). Он обладает специфическим сродством к $\mathrm{N}$-ацетилглюкозамину и его олигомерам $[42$, p. 850]. Связывание АЗП даже в большой концентрации с гифами патогенного гриба Fusarium роае не ингибировало их роста. Кроме того, лектин пшеницы стимулировал рост бактерий Ervinia raponticy, активировал прорастание спор гриба Aspergillus flavus [40, p. 490; 44, p. 196]. Для фитопатогенных бактерий Agrobacterium tumefaciens показано, что связывание бактериальных клеток с клетками или протопластами моркови с участием лектина приводило к совместному взаимодействию, то есть размножению бактериальных клеток и заражению растений. Авторы предположили, что плазмалемма растительной клетки может содержать специфический рецептор (лектин) для вирулентных клеток [43, p. 30]. 
Таким образом, значительное распространение лектинов в разных систематических группах растений, их наличие практически во всех органах и тканях растений, а также биологическая активность подтверждают важную роль этих белков в процессах жизнедеятельности. Так как лектины принимают участие в образовании белок-гликопротеиновых и полисахаридных комплексов, лектин-углеводное взаимодействие может определять процесс межклеточного распознавания, который основан на специфическом связывании рецептор-лиганд, что обуславивает совместимость при взаимодействии растения и патогена. Лектин может служить рецептором для распознавания растением широкого набора патогенов благодаря способности взаимодействовать с разными макромолекулами микроорганизмов при наличии в их составе характерной для лектина углеводной группы, доступной для контакта на начальных этапах инфицирования. Индуцированная лектин-углеводным распознаванием реализация экспрессии генетической информации механизма устойчивости растений является важным звеном защитной системы растений от фитозаболеваний.

Проведенный нами анализ лектиновой активности при прорастании контрольных растений свидетельствовал о том, что взятые в изучение сорта, линии пшеницы, ячменя и линии кукурузы имели как черты сходства, так и значительные различия по уровню лектиновой активности и характеру ее изменения в динамике, а лектиновая активность в тканях корней, как правило, была выше, чем в тканях надземной части проростков. Под действием грибных патогенов и индуктора устойчивости салициловой кислоты происходило изменение активности лектинов зародышей, растворимых лектинов и лектинов клеточных стенок проростков пшеницы, ячменя и кукурузы. Характер данных изменений зависел, прежде всего, от устойчивости сортов и линий зерновых культур к патогену, которая генетически детерминирована [1, с. $113-114 ; 21$, с. $43-44 ; 22$, с. 498-499; 26, с. 9-10; 27, с. 167-168]. Для устойчивых сортов пшеницы было характерно более значительное, по сравнению с восприимчивыми, повышение активности лектинов в зародышах и проростках при заражении возбудителями фузариоза и альтернариоза [2, с. 43-44]. Аналогичная картина по характеру изменения активности лектинов клеточных стенок регистрировалась в проростках ячменя и кукурузы при заражении возбудителями фуза- 
риоза. Изменения активности лектинов зародышей ячменя при инфицировании возбудителями фузариоза и гельминтоспориоза имели противоположную направленность [3, с. 28-30]. С использованием корреляционного анализа были установлены положительные взаимосвязи между изменением активности лектинов в зародышах и проростках, инфицированных грибными патогенами и уровнем устойчивости сортов, линий пшеницы к возбудителям фузариоза ( $\mathrm{r}=0,84$ (в зародышах); $\mathrm{r}=0,82$ (в проростках) при $\mathrm{p}=0,05$ соответственно) и к возбудителям альтернариоза ( $\mathrm{r}=0,91$ при $\mathrm{p}=0,05$ в зародышах); уровнем устойчивости сортов ярового ячменя к возбудителям фузариоза $(\mathrm{r}=0,79$ (в зародышах); r=0,85 (в проростках) при $\mathrm{p}=0,05)$ и к возбудителям гельминтоспориоза (r=0,69 при $\mathrm{p}=0,05$ в зародышах).

Влияние салициловой и жасмоновой кислот вызывало увеличение активности лектинов в надземной части и корнях проростков устойчивых и восприимчивых сортов пшеницы. Совместное действие патогена и салициловой или жасмоновой кислоты вызывало увеличение активности лектинов относительно контроля в надземной части и корнях проростков как устойчивых, так и восприимчивых сортов зерновых культур [26, с. 9-10; 27, с. 167-169].

Наблюдаемые изменения активности лектинов под действием изученных неблагоприятных факторов у разных по уровню устойчивости к грибным патогенам сортов и линий зерновых культур можно объяснить различной скоростью мобилизации запасных лектиновых мРНК для биосинтеза этих белков. Проведенное исследование экспрессии генов лектина пшеницы при инфицировании возбудителями фузариоза, альтернариоза и действии салициловой кислоты показало, что у устойчивых сортов пшеницы происходило достоверное увеличение мРНК относительно контроля на всех фонах проращивания (салициловая кислота, Fusarium graminearum, Alternaria alternata, салициловая кислота + Fusarium graminearum, салициловая кислота + Alternaria alternata), а у восприимчивых - уменьшение их содержания относительно контроля [25, с. 57-58]. Установленные же в данной работе и другими исследователями [13, с. 226; 35, с. 104-105] изменения активности лектинов и количества лектиновых мРНК под действием салициловой кислоты свидетельствуют об их участии в цепи сигнальных путей, ведущих к изменению экспрессии генов лектина. 
Обработка циклогексимидом инфицированных проростков достоверно снижала активность лектинов как у устойчивых, так и у восприимчивых сортов злаковых культур. В проростках, обработанных салициловой кислотой, под влиянием ингибитора синтеза белка наблюдалось уменьшение активности лектинов в надземной части и корнях проростков устойчивых сортов и в корнях восприимчивых сортов (в 1,$16 ; 1,33 ; 2,0$ раза соответствено). В проростках, обработанных жасмоновой кислотой, циклогексимид снижал активность лектинов в 1,3-2,0 раза как в надземной части, так и в корнях устойчивых и восприимчивых сортов растений. Такая реакция растений на действие ингибитора синтеза белка свидетельствует о наличии разных путей регуляции уровня лектинов. По всей вероятности, изменение активности лектинов у вегетирующи растений при действии грибных патогенов и индукторов устойчивости может контролироваться як на транскрипционном, так и на посттранскрипционном и посттрансляционном уровнях [26, с. 452].

Основой биологической активности лектинов является их участие в углеводно-белковых взаимодействиях, поэтому нами было проведено изучение углеводной специфичности лектинов для качественной характеристики этих белков. Проведенными исследованиями было показано, что сорта и линии изученных зерновых культур уже на уровне контрольных растений характеризовались неодинаковой углеводной специфичностью лектинов к 10 испытуемым сахарам. У устойчивых сортов пшеницы сродство лектинов к аминосахарам как в корнях, так и в надземной части проростков было ниже, чем у восприимчивых сортов, однако у устойчивых сортов наблюдалось сродство к D-глюкозе, D-фруктозе и D-рафинозе (1M), которое отсутствовало у восприимчивых сортов, линий пшеницы и у других культур. У устойчивых сортов ячменя и линий кукурузы в надземной части проростков сродство лектинов к аминосахарам было выше, чем у восприимчивых форм этих злаков. Сродство лектинов клеточных стенок корней к аминосахарам в проростках устойчивых и восприимчивых сортов, линий этих культур характеризовалось обратной зависимостью.

При грибной инфекции и действии салициловой кислоты происходили изменения углеводной специфичности лектинов проростков, которые коррелировали с уровнем устойчивости сортов и линий зер- 
новых культур к фузариозу. Устойчивые к фузариозу сорта пшеницы характеризовались повышением сродства лектинов к аминосахарам в надземной части проростков и снижением их углеводной специфичности к аминосахарам и D-фруктозо-6-фосфату в корнях при инфицировании возбудителями фузариоза. Устойчивые к фузариозу сорта ячменя отличались от восприимчивых снижением сродства лектинов к аминосахарам и D-фруктозо-6-фосфату в надземной части проростков и сохранением углеводной специфичности лектинов к аминосахарам и D-фруктозо-6-фосфату на уровне контроля в корнях. У устойчивых линий кукурузы в инфицированных растениях наблюдалось сохранение углеводной специфичности лектинов к аминосахарам, D-фрукто30-6-фосфату на уровне контроля.

При действии салициловой кислоты были установлены особенности изменения углеводной специфичности лектинов проростков разных зерновых культур. У устойчивых и восприимчивых к фузариозу сортов пшеницы было отмечено снижение сродства лектинов к аминосахарам и D-фруктозо-6 фосфату при действии салициловой кислоты как в надземной части, так и в корнях проростков. В растениях ячменя салициловая кислота не изменяла сродство лектинов к аминосахарам, D-фруктозо-6-фосфату в надземной части и корнях проростков устойчивых и восприимчивых сортов, а у кукурузы под действием салициловой кислоты наблюдалось значительное повышение сродства лектинов к аминосахарам в корнях проростков восприимчивых к фузариозу линий. Такие изменения углеводной специфичности лектинов клеточных стенок проростков зерновых культур при действии грибной инфекции и индукторов устойчивости обусловлены, с одной стороны, ингибированием лектиновой активности углеводами, в избытке накапливающимися при гидролизе полисахаридов клеточных стенок растений при инфицировании грибными патогенами, а с другой стороны, по-видимому, конформационными преобразованиями белков, в результате чего изменяется доступность сахаров к другим углеводсвязывающим центрам, или появлением изоформ лектинов, отличающихся по степени сродства к углеводам.

С использованием гель-фильтрации, аффинной хроматографии на бромцианактивированной овомукоид-сефарозе 4В, изоэлектрофокусирования были выделены и очищены лектины клеточных стенок из 
проростков зерновых культур, выращенных в контрольных условиях, при инфицировании возбудителями фузариоза, действии салициловой кислоты, совместном действии этих факторов, и изучены их биохимические свойства. Полученные результаты показали, что выделенные лектины имеют молекулярную массу около 27,0 кД, изоэлектрические точки в зонах $\mathrm{pH} 5,25-6,85 ; 7,22-7,74 ; 8,16-8,70 ; 9,57-9,74$ (максимальной активностью лектинов с pI 7,37 и 8,89 (для пшеницы), с pI 7,76 и 8,19 (для ячменя) и pI 7,78 (для кукурузы), характеризуются высоким сродством к $\mathrm{N}$-ацетилглюкозамину, наличием в аминокислотном составе значительного количества аспарагиновой, глутаминовой кислот, лейцина, глицина, серина и низким содержанием треонина, аланина, фенилалаланина, что согласуется с литературными данными по исследованию биохимических свойств лектинов злаковых культур [24, с. 113-116; 42, p. 850]. Установлено, что выделенные лектины обладают ингибирующим действием против фузариозных грибов Fusarium graminearum, Fusarium culmorum, Fusarium moniliforme, а при предварительной обработке зерна или введении в среду проращивания положительно влияют на ростовые процессы и индуцируют защитные биохимические реакции растений зерновых культур при поражении фузариозной инфекцией (активность ингибитора трипсина, эндогенных лектинов, фенилаланинаммиаклиазы). Из проведенных исследований был сделан вывод о том, что лектины зародышей, растворимые лектины и клеточных стенок проростков вовлечены в формирование защитных механизмов злаковых растений при инфицировании грибными патогенами и влиянии сигнальных молекул - салициловой и жасмоновой кислот.

\section{3. Роль лектинов в адаптивных реакциях при действии абиотических стрессоров}

При различных стрессовых воздействиях в растениях происходят значительные изменения в гормональном балансе клеток, которые вносят свой вклад в изменение структуры и функций клеток растительных организмов в обычных условиях на стрессовые программы. Значительную роль в регуляции изменения генной экспрессии в клетках растений при стрессе отводят абсцизовой кислоте (АБК), уровень которой в этих условиях значительно возрастает, что, способствует, с 
одной стороны, снижению активности метаболических процессов в клетках, в частности тотального синтеза белка и индукции новообразования более десятка стрессовых белков - с другой. Наряду с синтезом стрессовых белков в неблагоприятных условиях, а также при обработке экзогенной АБК, происходит усиление синтеза ряда присущих норме белков, к которым относится и лектин. В пользу этого свидетельствуют данные о существенном накоплении лектина в корешках проростков пшеницы при воздействии осмотического шока и засухи, в проростках в ответ на засоление среды, низкие температуры, в культуре клеток при тепловом шоке, а также в развивающихся при дефиците влаги зерновках пшеницы [12, с. 1009-1020; 35, с. 98-102]. Во многих случаях действие абиотического стресса приводило к транзитным пикам содержания (активности) лектинов в растении, в определенных органах или органеллах.

Интересны сведения о возможных механизмах криопротекторного эффекта галактозоспецифических лектинов ряда растений на изолированные тилакоидные мембраны хлоропластов из листьев. Благодаря относительной гидрофобности эти лектины могут связываться с гликолипидами мембран, что в свою очередь может способствовать укреплению мембранных структур тилакоидов и снижению их текучести вследствие повреждения, вызванного промораживанием. Анализ сезонных изменений в уровне лектинов листьев омелы, которые достигают максимального значения в зимние месяцы, наряду с данными об их защитном эффекте на изолированные тилакоидные мембраны шпината указывает на вероятность вовлечения лектинов в связывание с гликолипидами, присутствующими в большинстве клеточных мембран, и, таким образом, в стабилизацию мембранных структур листьев омелы in vitro при промораживании [12, с. 1010-1020].

Одним из механизмов защитного действия лектинов при стрессах различной природы является возможное влияние этих белков на цикл дестабилизации и стабилизации цитоскелета, играющего ключевую роль в регуляции реакции растения на биотические и абиотические стимулы. Обнаружено, что многие белки, связанные с элементами цитоскелета, модифицированы остатками $\mathrm{N}$-ацетилглюкозамина. Лектины, специфичные к хитоолигосахаридам, в частности АЗП, способны взаимодействовать с остатками $\mathrm{N}$-ацетилглюкозамина гли- 
коньюгатов и могут быть использованы для обнаружения модифицированных белков. Считается, что такая модификация обратима и очень мобильна, выполняет регуляторные функции подобно фосфорилированию. Она обнаружена у многих цитоплазматических и ядерных белков. Увеличение содержания лектинов приводит также к ингибированию окислительного стресса и снижению активных форм кислорода, что наряду со стабилизацией новой конфигурации цитоскелета возвращает клетку в невозбужденное состояние [12, с. 1019; 34, с. 120].

Проведенные нами исследования показали, что действие абиотических неблагоприятных факторов (водного дефицита, гипертермии, совместного их действия) вызывало значительное увеличение (в 2-5 раз) активности растворимых лектинов и лектинов клеточных стенок проростков засухоустойчивых сортов, линий зерновых культур, а у слабозасухоустойчивых - снижение или сохранение их активности на уровне контрольных растений. С использованием модельной выборки генетически близких линий кукурузы, различающихся по уровню засухоустойчивости, и данных корреляционного анализа были обнаружены статистически значимые взаимосвязи между изменением активности растворимых лектинов и лектинов клеточных стенок проростков кукурузы, подвергнутых действию водного дефицита и гипертермии, и уровнем засухоустойчивости линий [4, с. 332-336; 22 , с. $498-502 ; 23$, с. 26]. Засухоустойчивые сорта и линии зерновых культур отличались от слабозасухоустойчивых увеличением сродства лектинов к аминосахарам, галактозе, рафинозе в проростках, подвергнутых действию неблагоприятных абиотических факторов [22, с. 501].

Приведенные литературные и наши данные позволяют рассматривать лектин в качестве участника неспецифических защитных реакций растений.

\section{4. Выводы}

Лектинам принадлежит важная роль в межклеточных взаимодействиях и формировании защитных реакций растений при действии биотических и абиотических факторов окружающей среды. Индуцированная лектин-углеводным взаимодействием реализация экспрессии генетической информации механизмов устойчивости растений является одним из этапов активации их биохимической системы защиты. 
Изменение активности и углеводной специфичности лектинов при инфицировании и воздействии абиотических факторов может служить сигналом для запуска других защитных реакций и формирования мультикомпонентного биохимического ответа растения на неблагоприятные условия выращивания. Дальнейшие исследования в этом направлении открывают перспективы для использования уровня изменения лектиновой активности в тканях растениях при инфицировании и воздействии абиотических факторов в качестве биохимического критерия для оценки устойчивости растений к биотическим и абиотическим неблагоприятным факторам, а препаратов лектинов как индукторов устойчивости растений к стрессовым воздействиям различной природы.

В лаборатории биохимии растений СГИ-НЦСС была теоретически обоснована и экспериментально реализована методология оценки селекционного материала пшеницы и ячменя на устойчивость к возбудителям фузариоза, альтернариоза, гельминтоспориоза (по изменению активности лектинов при инфицировании патогеном) в зерне, зародышах и проростках зерновых культур с использованием в качестве стандартов сортов-эталонов и методов многомерной статистической обработки данных [5, с. 1-2; 7, с. 15-20]. Выявленная способность экзогенного лектина сои вызывать дифференцированное изменение активности ингибитора трипсина, эндогенных лектинов, фенилаланинаммиаклиазы растений в зависимости от уровня устойчивости к фузариозным грибам, позволила разработать метод использования экзогенного лектина сои для отбора устойчивых к фузариозу сортов пшеницы и ячменя [8, с. 15-18]. Впервые был предложен биохимический экспресс-метод оценки засухоустойчивости линий и гибридов кукурузы по изменению активности лектинов в проростках, подвергнутых влиянию водного дефицита и гипертермии [6, с. 2-3].

\section{Список литературы:}

1. Адамовская В.Г., Молодченкова О.О., Цисельская Л.Й., Левицкий Ю.А. Участие салициловой кислоты, лектинов, каталазы в реакциях устойчивости злаковых культур при фитозаболеваниях. Украинский биохимический журнал. 2002. Т. 74. № 46. С. 113-114.

2. Адамовська В.Г., Молодченкова О.О., Литвиненко М.А., Цісельська Л.І., Бірюков С.В. Лектини клітинних стінок проростків озимої пшениці при ураженні Fusarium spp. та дії саліцилової кислоти. Збірник наукових пращь СГI. 2003. Вип. 4(44). С. 27-31. 
3. Адамовская В.Г., Молодченкова О.О., Линчевский А.А., Цисельская Л.Й. Лектины клеточных стенок проростков ячменя при поражении Fusarium culmorum и действии салициловой кислоты. Физиология и биохимия культурных растений. 2005. Т. 37, № 3. С. 267-274.

4. Адамовская В.Г., Молодченкова О.О., Белоусов А.А., Соколов В.М., Тихонова О.В., Попов С.В., Безкровная Л.Я., Якименко И.А. Активность нитратредуктазы и лектинов клеточных стенок у растений кукурузы, выращенных в условиях водного дефицита и теплового шока. Физиология и биохимия культурных растений. 2010. Т. 41, № 4. С. 330-338.

5. Адамовська В.Г., Лінчевський А.А., Молодченкова О.О., Цісельська Л.Й., Бірюков С.В., Бабаянц О.В. Деклараційний патент на винахід № 43280A, Україна, А01Н1/04. Спосіб оцінки генотипів ярого ячменю на стійкість до фузаріозу. Бюл. № 10, Заяв. 06. 06. 2001, Опубл. 05.11.2001 р.

6. Адамовська В.Г., Молодченкова О.О., Бєлоусов А.О., Соколов В.М., Рищакова О.В. Патент № 49643, Україна. Спосіб оцінки посухо-жаростійкості ліній і гібридів кукурудзи. Бюл. № 9, Заявл. 05.10.2009, Опубл. 11.05. 2010 р.

7. Адамовська В.Г., Молодченкова О.О., Цісельська Л.Й., Безкровна Л.Я., Рищакова О.В. Оцінка селекційного матеріалу зернових культур на стійкість до фузаріозу за біохімічними показниками. Методичні рекомендаиії. Одеса, 2010. 25 с.

8. Адамовська В.Г., Молодченкова О.О., Цісельська Л.Й., Сагайдак Т.В., Рищакова О.В. Використання лектину сої в якості індуктора стійкості для добору стійких до фузаріозу сортів зернових культур. Методичні рекомендаuіiі. Одеса, 2010. 20 c.

9. Антонюк В.О. Лектини та їх сировинні джерела. Львів: ПП «Кварт», 2005. $554 \mathrm{c}$.

10. Антонюк Л.П., Игнатов В.В. О роли агглютинина зародыша пшеницы в растительно-бактериальном взаимодействии: гипотеза и экспериментальные данные в ее поддержку. Физиология растений. 2001. Т. 48, №. 3. С. 427-433.

11. Антонюк В.А., Луцик М.Д., Ладная Л.Я. Сезонные изменения титра гемагглютинации и сродства к углеводам экстрактов растений, содержащих фукозоспецифические лектины. Физиология растений. 1982. Т. 29, № 6. C. $1219-1224$.

12. Бабоша А.В. Индуцибельные лектины и устойчивость растений к патогенным организмам и абиотическим стрессам. Биохимия. 2008. Т. 73, Вып. 7. С. 1007-1022.

13. Белава В.Н., Панюта О.О., Таран Н.Ю. Роль лектинів у захисних реакціях рослин до фітопатогенів. Физиология и биохимия культурных растений. 2009. T. 41, № 3. С. 221-233.

14. Выскребенцова Э.И., Борисова Н.Н. Распределение лектиновой активности в митохондриях корнеплода сахарной свеклы: лектиновая активность мембран и матрикса митохондрий корнеплода сахарной свеклы. Физиология растений. 1996. Т. 43, № 4. С. 527-532.

15. Громова Б.Б., Патрикеева М.В., Житлева М.А. Методика определения неспеиифической устойчивости картофеля к возбудителям фитофтороза по лектинам листьев. Л.: ВИЗР, 1990. 12 с. 
16. Комарова Э.Н., Выскребенцова Э.И., Трунова Т.И. Изменение лектиновой активности клеточных стенок этиолированных проростков озимой пшеницы в процессе закаливания к морозу. Доклады академии наук. 1993. Т. 329, № 5. С. 680-685.

17. Коць С.Я., Маменко П.М., Маличенко С.М. Структурные особенности и биологические функции лектинов. Физиология и биохимия культ. Растений. 2008. T.40, № 2. C. $120-125$.

18. Луцик М.Ф., Панасюк Е.Н., Луцик А.Д. Лектиныл. Львов: Выща школа, 1981. $150 \mathrm{c}$.

19. Любимова Н.В., Салькова Е.Г. Лектин-углеводное взаимодействие во взаимоотношениях растение-патоген. Прикладная биохимия и микробиология. 1988. T. 24, № 1. C. 110-117.

20. Любимова М.В., Щербухин В.Д. Процессы межклеточного узнавания и индуцированной устойчивости клубней картофеля к болезням (Обзор). Прикладная биохимия и микробиология. 1991. Т. 27. С. 3-16.

21. Молодченкова О.О., Адамовская В.Г., Левицкий Ю.А., Соколов В.М. Ответная реакция растений кукурузы на действие салициловой кислоты и Fusarium moniliforme. Прикладная биохимия и микробиология. 2002. Т. 36, № 4. C. 441-446.

22. Молодченкова О.О., Адамовская В.Г., Тихонова О.В., Вареник Б.Ф. Особенности ответных реакций проростков кукурузы при воздействии биотических и абиотических факторов. Физиология и биохимия культурных растений. 2007. Т. 39, № 6. С. 496-504.

23. Молодченкова О.О. Влияние салициловой кислоты на ответные реакции проростков кукурузы при абиотических стрессах. Вісник Харківського аграрного університету. Серія Біологія. 2008. Вип. 3(15). С. 24-32.

24. Молодченкова О.О., Адамовская В.Г., Цисельская Л.Й., Сагайдак Т.В. Выделение и свойства лектинов клеточных стенок из проростков пшеницы, инфицированных Fusarium graminearum и обработанных салициловой кислотой. Украинский биохимический журнал. 2010. Т. 82, № 5. С. 111-117.

25. Молодченкова О.О., Адамовская В.Г., Досенко В.Е., Тихонов П.С. Лектиновая активность и экспрессия генов лектина проростков пшеницы при инфицировании грибными патогенами и действии салициловой кислоты Вестник Харьковского национального аграрного университета. Серия Биология. 2012. Вып. 2(26). С. 54-60.

26. Молодченкова О.О., Адамовська В.Г. Захисні реакції рослин пшениці за дії фузаріозної інфекції, саліцилової та жасмонової кислот. Фізіологія рослин та генетика. 2015. Т. 47. С. 8-12.

27. Молодченкова О.О., Адамовська В.Г., Лихота О.Б., Безкровна Л.Я, Левицький Ю.А., Рищакова О.В., Картузова Т.В. Біохімічні захисні реакції злакових рослин за дії біотичних і абіотичних чинників довкілля. Вісник Львівського університету. 2016. Вип. 73. С. 166-170.

28. Серова 3.Я., Юшко Л.С., Подчуфарова Г.М. Функичии белков в патогенезе. Минск: Навука і тэхніка, 1992. С. 34-35.

29. Созинов А.А. Полиморфизм белков и его значение в генетике и селекиции. Москва: Наука, 1985. 270 с. 
30. Сытников Д.М., Коць С.Я. Участие лектинов в физиологических процессах растений. Физиология и биохимия культурных растений. 2009. Т. 41, № 4. С. 281-294.

31. Тарчевский И.А. Метаболизм растений при стрессе. Казань: Фен, 2001. 448 c.

32. Хайруллин Р.М., Шакирова Ф.М., Безрукова М.В. Накопление лектина и абсцизовой кислоты в проростках пшеницы под воздействием препаратов аминового ряда бисола 2 и базурана. Новые средства и методы защиты растений. Уфа: БНЦ УрО РАН, 1992. С. 112-117.

33. Хайруллин Р.М., Шакирова Ф.М., Максимов И.В. Изучение содержания лектина, абсцизовой и индолилуксусной кислот в растениях пшеницы, инфицированных Septoria S. novorum. Berk. Физиология и биохимия культурных растений. 1993. Т. 25, № 2. С. 138-144.

34. Шакирова Ф.М., Безрукава М.В. Современные представления о предполагаемых функциях лектинов растений. Журнал общей биологии. 2007. T. 68, № 2. C. 109-125.

35. Шакирова Ф.М. Неспецифическая устойчивость растений к стрессовым факторам и ее регулящия. Уфа: Гилем, 2001. 160 с.

36. Шалимова О.А., Гагарина И.Н., Прудникова Е.Г., Павловская Н.Е. Влияние лектинов растительного происхождения и препарата Эпин на неспецифический иммунитет зерновых и зернобобовых культур. Агрохимия. 2005 № 12. С. $36-41$.

37. Ямалеева А.А. Лектины посевной и дикорастущей гречихи в исследовании исходного селекционного материала и действии биорегулятора гуми. Информ. Вестн. ВОГСиС. 2002. № 18. С. 3-6.

38. Bartlett J., Stirling D., Press H. (2003) PCR Protocols, 2nd ed. 2701351, 556 p.

39. Chrispeels M.J., Raikhel N.V. (1991). Lectin, lectin genes and their role in plant defense. Plant Cell, vol. 3, pp. 1-9.

40. Barraqueta-Egea P., Schauz K. (1983). The influence of phytolectins on spore germination of Tilletia caries, Puccinia graminis and Aspergillus flavus. Pflanzenkrankrheiten und Pflanzenschutz, vol. 90, pp. 488-495.

41. Gibson D.M., Sharon S.L., House K.J. (1982). A comparison of soybean agglutinin in cultivars resistant and susceptible to Phytophthora megasperma var sojae (Race 1). Plant Physiology, vol. 70, pp. 560-566.

42. Levine D. (1972). The purification and characterization of wheat-germ agglutinin. Biochemistry J, vol. 129, pp. 847-856.

43. Matthysse A.G., Holmes K.V., Gurlitz R.G. (1982). Binding of Agrobacterium tumefaciens to carrot protoplasts . Ibid, vol. 20, no 1, pp. 27-33.

44. Poschenrider G., Huber S.J. (1982). Interaction of wheat germ agglutinin (lectin) with microconidia of Fusarium poae. Pflanzenk Pflanzenschutz, vol. 89, pp. 194-199.

\section{References:}

1. Adamovskaya V.G., Molodchenkova O.O., Ciselskaya L.Y., Levitsky Ya.A. (2002). Uchastie salicilovoy kisloty, lektinov, katalazy v reakciyakh ustoychivosti zlakobykh kul'tur pri fitozabolevaniyakh [The participation of salicylic acid, lectins, 
catalase in the reactions of the stability of cereal crops during phytodiseases]. The Ukrainian biochemical jornal, vol.74, no 4b , pp. 113-114. (in Russian)

2. Adamovs'ka V.G., Molodchenkova O.O., Litvinenko M.A., Cisel's'ka L.J., Birjukov S.V. (2003). lectiny klitunnukh stinok prorostkiv ozymoji pshenyci pry urazhenni Fusarium spp. ta diji salicylovoji kysloty [The lectins of the cell walls of winter wheat seedlings at the infection of Fusarium spp. and the action of salicylic acid]. Collection of research papers of PBGI-NCSCI, vol. 4(44), pp. 27-31. (in Ukrainian)

3. Adamovskaya V.G., Molodchenkova O.O., Linchevsky A.A., Ciselskaya L.Y. (2005). Lektiny kletochnykh stenok prorostkov yachmenya pri porazhenii Fusarium culmorum i deystvii salicilovoy kisloty [Lectins of the cell walls of barley seedlings at the infection of Fusarium culmorum and the actions of salicylic acid]. Physiology and biochemistry of cultivated plants, vol. 37, no 3, pp. 267-274. (in Russian)

4. Adamovskaya V.G., Molodchenkova O.O., Belousov A.A., Sokolov V.M., Tikhonova O.V., Popov S.V., Bezkrovnaya L.Y., Yakimenko I.A. (2010). Aktivnost' nitratreduktazy i lektinov kletochnykh stenok u rasteniy kukuruzy, vyrashchennykh $\mathrm{v}$ usloviyakh vodnogo deficita i teplovogo shoka [Activity of nitrate reductase and cell wall lectins in corn plants grown under conditions of water deficiency and heat shock]. Physiology and biochemistry of cultivated plants, vol. 41, № 4, pp. 330-338. (in Russian)

5. Adamovska V.G., Linchevsky A.A., Molodchenkova O.O., Ciselska L.Y., Birjukov S.V., Babajanc O.B. (2001). Deklaraciynyy patent na vynakhid № 43280A, Ukrajina, A01H1/04. Sposib ocinky genotypiv jarogo jachmenju na stiykist' do fuzariozu [Declarative patent for an invention \# 43280, Ukraine, A01H1/04. Method of estimation the genotypes of spring barley on resistance to fusariosis]. Bul. no 10, Declared 06. 06. 2001, Published 05.11.2001. (in Ukrainian)

6. Adamovska V.G., Molodchenkova O.O., Belousov A.O., Sokolov V.M., Ryshchakova O.V. (2010). Patent № 49643, Ukraina. Sposib ocinky posukhostijkosti i zharostijkosti liniy i gibridov kukurudzy[Patent \# 49643, Ukraine. Evaluation method of drought and heat resistance of corn lines and hybrids]. Bul. no 9, Declared 05.10.2009, Published 11.05. 2010. (in Ukrainian)

7. Adamovska V.G., Molodchenkova O.O., Ciselska L.Y., Bezkrovna L.Y., Ryshchakova O.V. (2010). Ocinka selekciynogo materialu zernovykh kuljtur na stijkistj do fuzariozu za biokhimichnymy pokaznykamy [Evaluation of breeding material for cereals on resistance to fusariosis by biochemical parameters]. Methodical recommendations. Odesa, 25 p. (in Ukrainian)

8. Adamovska V.G., Molodchenkova O.O., Ciselska L.Y., Sagaydak T.V., Ryshchakova O.V. (2010). Vykorystannja lektynu soji $\mathrm{v}$ jakosti induktora stijkosti dlja doboru stijkykh do fuzariozu sortiv zernovykh kuljtur [The use of soybean lectin as an inducer of resistance for the selection of fusarium-resistant varieties of cereals]. Methodical recommendations.Odesa, 20 p. (in Ukrainian)

9. Antonyuk V.O. (2005). Lekniny ta jikh syrovyn ni dzherela [Lectins and their primary courses]. Lviv: PP "Kvart". 554 p. (in Ukrainian)

10. Antonyuk V.O., Ignatov V.V. (2001). O roli agglyutinina zarodysha pshenitsy $\mathrm{v}$ rastitel'no-bakterial'nom vzaimodeystvii: gipoteza i eksperimental'nye dannye $\mathrm{v}$ eye podderzhku [About role of wheat germ agglutinin in the plant-bacterial 
interaction: hypothesis and experimental data in its support]. Russian Jornal of Plant Physiology, vol. 48, no. 3, pp. 427-433. (in Russian)

11. Antonyuk V.A., Lutsik M.D., Ladnaya L.Ya. (1982). Sezonnye izmeneniya titra gemagglutinatsii I srodstva k uglevodam ekstraktov rasteniy, soderzhashchikh fukozospecificheskie lektiny [Seasonal changes titer of hemagglutination and affinity for carbohydrates of plant extracts which contain fucose-specific lectins]. Russian Jornal of Plant Physiology, vol. 29, no 6, pp. 1219-1224. (in Russian)

12. Babosha A.V. (2008). Inducibel'nye lektiny i ustoychivost' rasteniy k patogennym organismam i abioticheskim stressam [Inducible lectins and plant resistance to pathogens and abiotic stress]. Biochemistry, vol. 73, no 7, pp. 1007-1022. (in Russian)

13. Belava V.N., Panyuta O.O., Taran N.Yu. (2009). Rolj lektyniv u zakhysnukh reakcijakh roslyn do fitopatogeniv [The role of lectins in the plants defence reactions to phytopathogens]. Physiology and biochemistry of cultivated plants, vol. 41, no 3, pp. 221-233. (in Ukrainian)

14. Vyskrebencova E.I., Borisova N.N. (1996). Raspredelenie lektinivoy aktivnosti v mitokhondriyakh korneploda sakharnoy svekly: lektinovaya aktivnost' мемbran i мatriksa mitokhondriy korneploda sakharnoy svekly [Distribution of lectin activity in the mitochondria of sugar beet root: lectin activity of the membranes and matrix of mitochondria of the sugar beet root]. Russian Jornal of Plant Physiology, vol. 43, no 4, pp. 527-532.

15. Gromova B.B., Patrikeeva M.V., Zhitleva M.A. (1990). Metodika opredeleniya nespecificheskoy ustoychivosti kartofelya $k$ vozbuditelyam fitiftoroza po lektinam list'ev [Methods for determining nonspecific resistance of potatoes to late blight pathogens by leaf lectins]. L.: VIZR, 12 p. (in Russian)

16. Komarova E.N., Vyskrebencova E.I., Trunova T.I. (1993). Izmenenie lektinovoy aktivnosti kletochnykh stenok etiolirovannykh prorostkov ozimoy pshenicy $\mathrm{v}$ processe zakalivaniya $\mathrm{k}$ morozu [Change in the lectin activity of the cell walls of etiolated winter wheat seedlings during hardening to frost]. Reports of the Academy of Sciences, vol. 329, no 5, pp. 680-685. (in Russian)

17. Kots S.Ya., Mamenko P.M., Malichenko S.M. (2008). Strukturnye osobennosti i biologicheskie funktsii lektinov [Structural features and biological functions of lectins]. Physiology and biochemistry of cultivated plants, vol. 40, no 2, pp. 120-125. (in Russian).

18. Lucik M.F., Panasyuk E.N., Lucik A.D. (1981). Lektiny [Lectins]. Lviv: Bysha shkola, 150 p. (in Russian).

19. Lyubimova N.V., Sal'kova E.G. (1988). Lektin-uglevodnoe vzaimodeystvie vo vzaimootnosheniyakh rastenie-patogen[Lectin-carbohydrate interaction in plant-pathogen relationships]. Applied Biochemistry and Microbiology, vol. 24, no 1, pp. 110-117. (in Russian)

20. Luybimova M.V., Shcherbukhin V.D. Processy mezhkletochogo uznavaniya $\mathrm{i}$ inducirovannoy ustoychivosti klubney kartofelya $\mathrm{k}$ boleznyam (Obzor) [The processes of intercellular recognition and induced resistance of potato tubers to diseases (Review)]. Applied Biochemistry and Microbiology, vol. 27, pp. 3-16. (in Russian) 
21. Molodchenkova O.O., Adamovskaya V.G., Levitsky Yu.A., Sokolov V.M. (2002). Otvetnaya reakciya rasteniy kukuruzy na deystvie salicilovoy kisloty i Fusarium moniliforme [The response reaction of corn plants to the action of salicylic acid]. Applied Biochemistry and Microbiology, vol. 36, no 4, pp. 441-446. (in Russian)

22. Molodchenkova O.O., Adamovskaya V.G., Tichonova O.V., Varenik B.F. (2007). Osobennosti otvetnykh reakciy prorostkov kukuruzy pri vozdeystvii bioticheskikh i abioticheskikh faktorov [Features of responses of corn seedlings at the action of biotic and abiotic factors]. Physiology and biochemistry of cultivated plants, vol. 39, no 6, pp. 496-504. (in Russian)

23. Molodchenkova O.O. (2008). Vliyanie salicilovoy kisloty na otvetnye reakcii prorostkov kukuruzy pri abioticheskikh stressakh [The influence of salicylic acid on the response reactions of corn seedlings under abiotic stress]. Bulletin of the Kharkov Agricultural University. Biology Series, vol. 3(15), pp. 24-32. (in Russian)

24. Molodchenkova O.O., Adamovskaya V.G., Ciselskaya L.Y., Sagaydak T.V. (2010). Vydelenie i svoystva lektinov kletochnykh stenok iz prorostkov pshenicy, inficirovannykh Fusarium graminearum i obrabotannykh salicilovoy kislotoy. [Isolation and properties of cell wall lectins from seedlings infected with Fusarium graminearum and treated by salicylic acid]. Ukrainian biochemical journal, vol. 82, no 5, pp. 111-117. (in Russian)

25. Molodchenkova O.O., Adamovskaya V.G., Dosenko V.E., Tichonov P.S. (2012). Lektinovaya aktivnost' I ekspressiya genov lektina prorostkov pshenicy pri inficirovanii gribnymi patogenami I deystvii salicilovoy kisloty [Lectin activity and gene expression of lectin from seedling of wheat at the infection by fungal pathogens and the action of salicylic acid]. Bulletin of the Kharkov Agricultural University. Biology Series, vol. 2(26), pp. 54-60. (in Russian)

26. Molodchenkova O.O., Adamovskaya V.G. (2015). Zakhysni reakcii roslyn pshenyci za diji fuzarioznoiji infekciji, salicylovoji ta zhasmonovoji kyslot [Protective reactions of plants wheat at the action of Fusarium infection, salicylic and jasmonic acids]. Plant physiology and genetics, vol. 47, pp. 8-12. (in Ukrainian)

27. Molodchenkova O.O., Adamovska V.G., Lykhota O.B., Bezkrovna L.Ja., Levitsky Ju.A., Ryshchakova O.V., Karruzova T.V. (2016). Biokhimichni zakhysni reakcii zlakobykh roslyn za diji biotychnykh i abiotychnykh chynnykiv dovkillja [Biochemical protective reactions of cereals under the action of biotic and abiotic environmental factors]. Bulletin of the University of Lviv, vol. 73, pp. 166-170. (in Ukrainian)

28. Serova Z.Ya., Yushko L.S., Podchufarova G.M. (1992). Funkcii belkov $\mathrm{v}$ patogeneze [Protein functions in pathogenesis]. Minsk: Navuka i tekhika, pp. 34-35. (in Russian)

29. Sozinov A.A. (1985). Polimorfizm belkov $i$ ego znachenie $v$ genetike $i$ selekcii [Protein polymorphism and its value in genetics and plant breeding]. M.: Nauka, 270 p. (in Russian)

30. Sytnikov D.M., Koc' S.Ya. (2009). Uchastie lektinov v fiziologicheskikh processakh rasteniy [The participation of lectins in the physiological processes of plants]. Physiology and biochemistry of cultivated plants, vol. 41, no 4, pp. 281-294. (in Russian) 
31. Tarchevsky I.A. (2001). Metabolism rasteniy pri stresse [Plant metabolism under stress]. Kazan': Fen, 448 p.

32. Khayrullin R.M., Shakirova F.M., Bezrukova M.V. (1992). Nakoplenie lektina i abscizovoy kisloty v prorostkakh pshenicy pod vozdeystviem preparatov aminovogo ryada bisola 2 i bazyrana. Novye sredstva $i$ metody zashchity rasteniy [The accumulation of lectin and abscisic acid in wheat seedlings under the influence of amine preparations of bisol 2 and bazuran. New means and methods of plant protection]. Ufa: BNC UrORAN, pp. 112-117. (in Russian)

33. Khayrullin R.M., Shakirova F.M., Maksimov I.V. (1993). Izuchenie soderzhaniya lektina, abscizovoy i indoliluksusnoy kislot $\mathrm{v}$ rasteniyakh pshenicy, inficirovannykh Septoria S. novorum. Berk. [Study of the content of lectin, abscisic and indolylacetic acids in wheat plants infected Septoria S. novorum. Berk.] Physiology and biochemistry of cultivated plants, vol. 25, no 2, pp. 138-144. (in Russian)

34. Shakirova F.M., Bezrukova M.V. (2007). Sovremennye predstavleniya o predpolagaemykh funkciyakh lektinov rasteniy [Modern views on the proposed functions of plant lectins]. Journal of General Biology, vol. 68, no 2, pp. 109-125. (in Russian)

35. Shakirova F.M. (2001). Nespecificheskaya ustoychivost' rasteniy k stressovym faktoram i ee regulyaciya [Nonspecific resistance of plants to stress factors and its regulation]. Ufa: Gilem, $160 \mathrm{p}$. (in Russian)

36. Shalimova O.A., Gagarina I.N., Prudnikova E.G., Pavlovskaya N.E. (2005). Vliyanie lektinov rastitel'nogo proiskhozhdeniya i preparata Epin na nespecificheskiy immunitet zernobykh i zernobobovykh kultur [The effect of plant lectins and Epin on nonspecific immunity of cereals and legumes]. Agrochemistry, no 12, pp. 36-41. (in Russian)

37. Yamaleeva A.A. (2002). Lectiny posevnoy I dikorastushchey grechichi v issledovanii ischodnogo selekcionnogo materiala I deystvii bioregulyatora [Cultivated and wild buckwheat lectins in research of initial breeding material and action of bioregulator].Vavilov Jornal of Genetics and Breeding, no 18, pp. 3-6. (in Russian)

38. Bartlett J., Stirling D., Press H. (2003). PCR Protocols, 2nd ed. 2701351, 556 p.

39. Chrispeels M.J., Raikhel N.V. (1991). Lectin, lectin genes and their role in plant defense. Plant Cell, vol. 3, pp. 1-9.

40. Barraqueta-Egea P., Schauz K. (1983). The influence of phytolectins on spore germination of Tilletia caries, Puccinia graminis and Aspergillus flavus. Pflanzenkrankrheiten und Pflanzenschutz, vol. 90, pp. 488-495.

41. Gibson D.M., Sharon S.L., House K.J. (1982) A comparison of soybean agglutinin in cultivars resistant and susceptible to Phytophthora megasperma var sojae (Race 1). Plant Physiology, vol. 70, pp. 560-566.

42. Levine D. (1972). The purification and characterization of wheat-germ agglutinin. Biochemistry J., vol. 129, pp. 847-856.

43. Matthysse A.G., Holmes K.V., Gurlitz R.G. (1982). Binding of Agrobacterium tumefaciens to carrot protoplasts. Ibid, vol. 20, no 1, pp. 27-33.

44. Poschenrider G., Huber S.J. (1982). Interaction of wheat germ agglutinin (lectin) with microconidia of Fusarium poae. Pflanzenk Pflanzenschutz, vol. 89, pp. 194-199. 